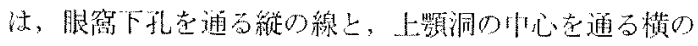

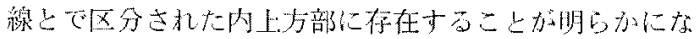

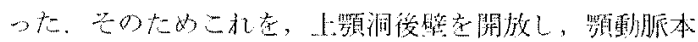

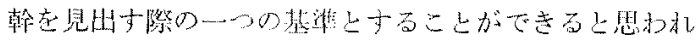
Ђ. $(|\mathrm{x}|-2)$

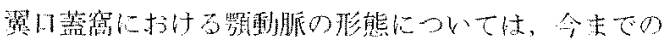

成霜，文擜等の記载は平面的なものが多いしかしなが

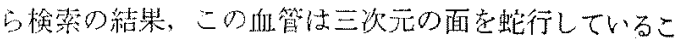

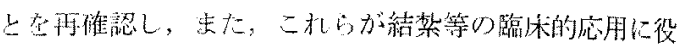
立》60区考学方。

( В 80-1191-33914)

\title{
118.『Kiesselbach 部位から』の鼻出血
}

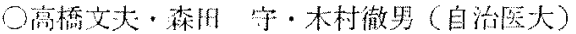

Episfaxis from $\mathbb{0}$ Kiesselbach's area』

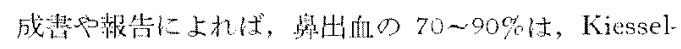

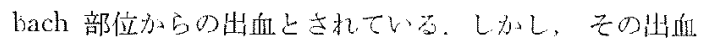

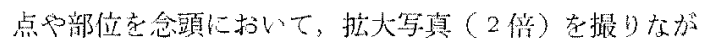

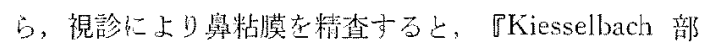

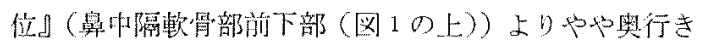

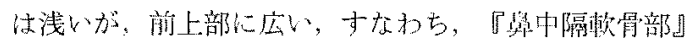

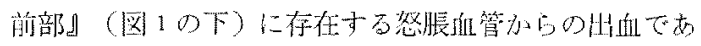

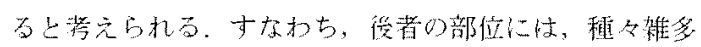

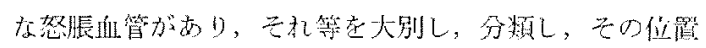

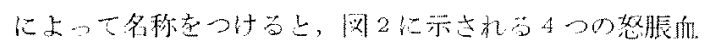

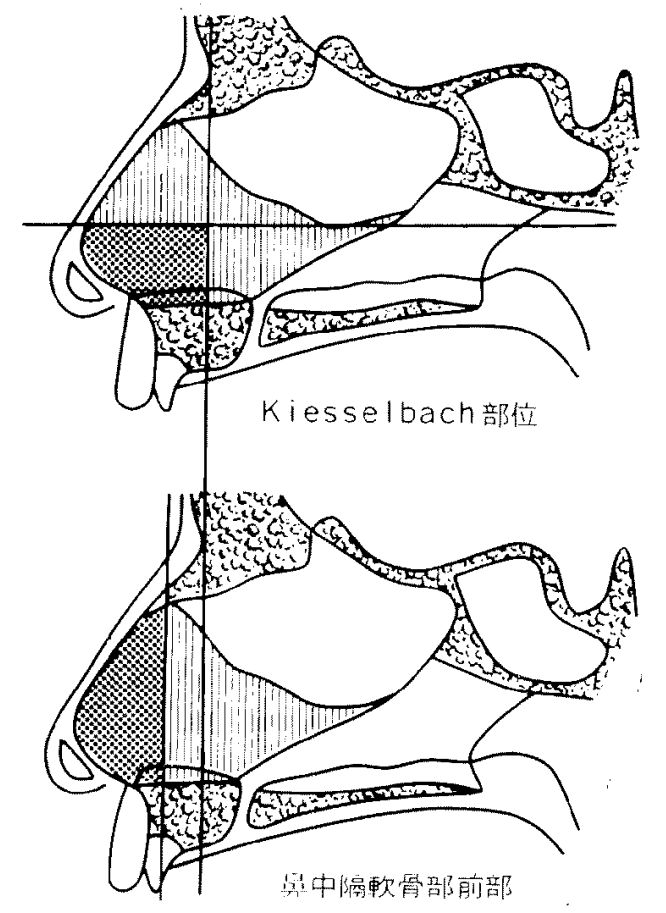

図 1

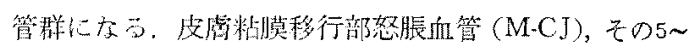
$7 \mathrm{~mm}$ 傒力で上に樹状にのぼる後下部怒脹血管，(P.I)筫

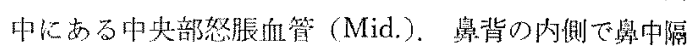
軟兴部に下がる前上部怒脤血管 (A-S)。である。これら

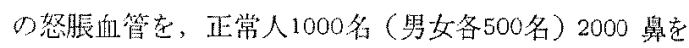

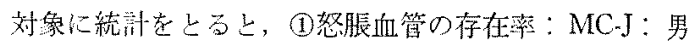
$28 \%$, 女 $26 \%$ で平均 $26 \%$, P.I：男 $7 \%$, 女 $3 \%$ 更平均 5 $\%$, A-S 男灰各 $1 \%$, Mid：罗女已も, 極少であるが, 全体で32\%蚛の存在上なる。(2)怒脏血管の左有差につ、

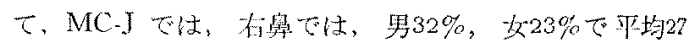

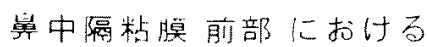

怒服血管の分布

站床上 0 名称

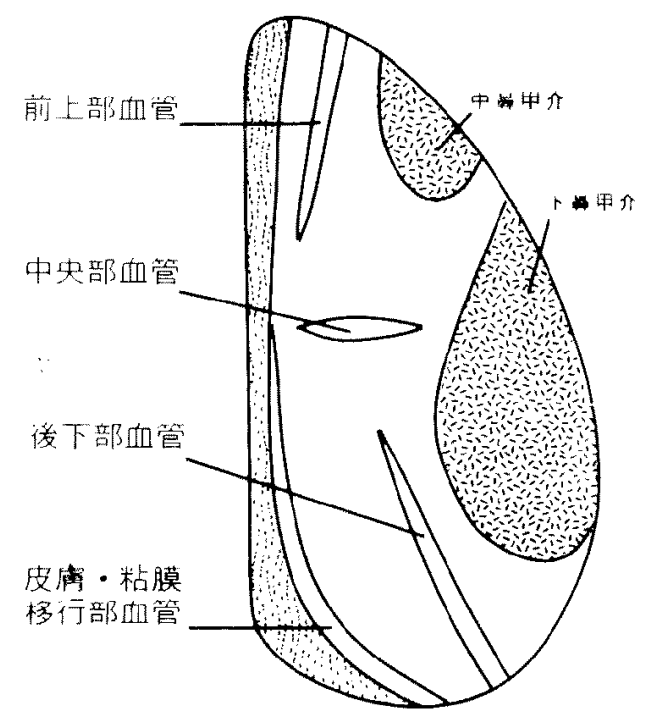

図 2 
$\%$ ，左鼻で江男 $24 \%$ ，女22\%で平均 $23 \%$ であ，在鼻に

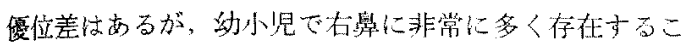
とが影響しているものである。P.I では，右鼻では、男

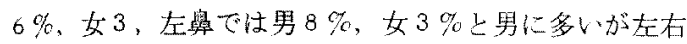
差㹥ない，A-Sでは左右差がなく，男女雨鼻共に1\%で ある。（3) 怒脹血管の年龄分布では，MC-Jでは，生兴 1 满才から出現し，20才までは，約30\%の鼻に存在し， 30才までは，隇少するが，その後も20\%には存在し，終 生消失しないものと考えられる，P-I では，男女とも30 才までは少ないが，40才以㖟の男子左舅では10\%以上に 達する、A-S, Mid，では，その存在は少农いが苏出血に 直接関係子るものが多いこの A-S からの出血索 Kiesselbach 部位に追加して，易出血部位应考光たい（4) 鼻出血の発生率：MC-J 怒脹血管を有している人の37\% は，章出血交経験しており，特に，幼小児男子では，約 40\%，10２0才代の女子と60才の男子では，共に高い摔 で経唤している。（5)止血処置を受けた率：前述 MC.Jが 西り，鼎出血索経験した35\%のうち，治療在受けたもの 注9\%であり，10才代の女子，60才代の男子が高い率在 示した。しかるにこの9\%は，全母集団1000人にとって
3\%にあたり，これは，日常の外来患者に占める買出血 㭧省の百分象に等しく，鼻出血の770 90\%は，Kiessel一 bach 部位からの出血であることを寨つけている。

次にMC-J怒脹血管になり得る血管として考えられ

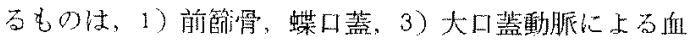
管網があり，その他に，顔面動脈の上唇動脈加ら分枝

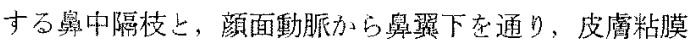
移行部直下八達寸る鼻翼下緑校驾ある。これらの2玟 は，顔面動脈の発達の程度に加わり，才大加ち，2枝 が同時に存在するか，片方のみ加，东たは，兩枝上るな いものがある。屍体21体の解剖では，菑翼下絯枝は18

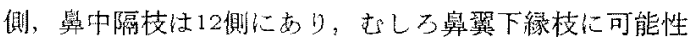
が大きい全体的々みて，1側以上あるものは17例で80 \%，両側存在しない子のが 4 例で20\%であった。

付記：成書によっても，Kiesselbach 部位の簌囲の表 現は、数種にのぼり, 鼻口部の後部, 舅中隔軟骨部, 舅 中隔前部，鼻中隔前庭部皮膚粘膜移行部などである。 1976年日耳鼻用語解説集が発行され，本来の Kiesselbach 部位である门鼻中隔軟骨部前下部」に規定された。

(B 80-1192-32781)

\section{9. 歯性上顎洞炎の臨床的研究}

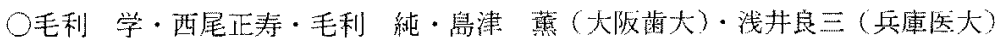

目的：1969年加51976年までの7年間に，㐘性上頡洞 炎110例について臨床的観察在行った結果, 從来の知識 ですべての臨床例管理するには限界のあること知。

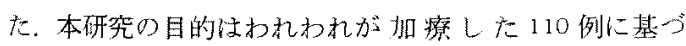
き, 本症の臨林的特徵の再楧討ならびに本症の病態在明 らかにして治漅法の確立を行らことである。

方法：X線撮影法に怯後頭・崩頭法, 後頭・鼻位法に

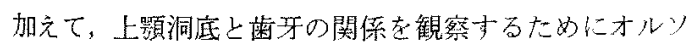
パントモグラフィ（歯科パノラマ撮影法）招よび口内法 撮影をルーチンとした。対象 110 例の55口腔上顎洞瘦 孔のある症例が61例あり，そのうち30例について瘦孔被 语による高濃度排泄機能検查法に上引手術適灾の決定を 行った。原因歯の抜崡が行わ札ていない山例にはす心゙て

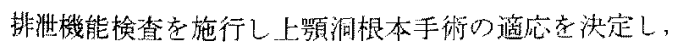

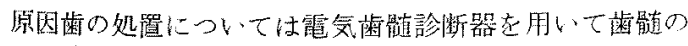
生死判定を行うとともにデンタルフィルムによって, 拔 歯京よび根管充增の適応在決定した。

躘床的事項
1）性别は男性51例，女性59例で両者の差はない。

2）患側は右側58例, 左側52例で左右別の差注ない.

3）年龄分布では20才代36例 $(32.7 \%)$ で最も多く, 30 才代35例 (31.8\%)，40才代 (19\%) ट次く

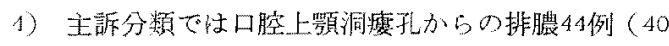
$\%$ ）上最多多人，悪臬鼻漏25例 $(22.7 \%)$ ，煩部痛 17 例 $(15.4 \%)$ 之次々。

5）鼻腔所見は54例に所見を認め，56例には特記す心゙ 意所見妾認めない。

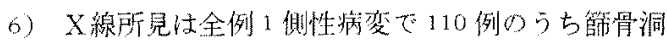

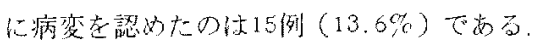

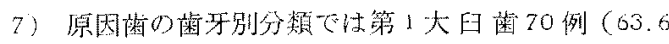
$\%$ ) 加最己多人，第2大田歯22例 $(20 \%)$ ，第 2 小 口承11例 $(10 \%)$ 上次〈。

病態分数

臨來経過㧍上び臨床所見から本症の病態を次のごとく 分類した。

I. 拔歯群………6.69例 